\title{
Specificity of an Extracellular Proteinase from Brevibacterium linens ATCC 9174 on Bovine $\beta$-Casein
}

\author{
FERGAL P. RATTRAY, ${ }^{1 *}$ PATRICK F. FOX, ${ }^{1}$ AND ÁINE HEALY ${ }^{2}$ \\ Department of Food Chemistry ${ }^{1}$ and National Food Biotechnology Centre, ${ }^{2}$ University College, Cork, Ireland
}

Received 16 December 1996/Accepted 4 April 1997

\begin{abstract}
The specificity of the extracellular proteinase from Brevibacterium linens ATCC 9174 on bovine $\beta$-casein was studied. Hydrolysis was monitored over time by sodium dodecyl sulfate-polyacrylamide gel electrophoresis (PAGE) and urea-PAGE. The major pH 4.6-soluble peptides were isolated by high-performance liquid chromatography and identified by $\mathrm{N}$-terminal amino acid sequencing and mass spectrometry. The major sites of hydrolysis were Ser-18-Ser-19, Glu-20-Glu-21, Gln-56-Ser-57, Gln-72-Asn-73, Leu-77-Thr-78, Ala-101-Met102, Phe-119-Thr-120, Leu-139-Leu-140, Ser-142-Trp-143, His-145-GIn-146, GIn-167-Ser-168, GIn-175-Lys176, Tyr-180-Pro-181, and Phe-190-Leu-191. The proteinase had a broad specificity for the amino acid residues present at the $P_{1}$ and $P_{1}^{\prime}$ positions but showed a preference for hydrophobic residues at the $P_{2}, P_{3}$, $\mathbf{P}_{4}, \mathbf{P}_{2}^{\prime}, \mathbf{P}_{3}^{\prime}$, and $\mathbf{P}_{4}^{\prime}$ positions.
\end{abstract}

The surface microflora of various smear surface-ripened cheeses, such as Limburger, Trappist, Münster, Brick, Appenzeller, and Tilsiter, includes yeasts, molds, and bacteria (1, 3 , $13,14)$. During the ripening of these cheeses, yeasts and molds dominate the surface microflora initially, metabolize lactate as a growth substrate, and consequently raise the curd $\mathrm{pH}$ (16). The reduced acidity permits the growth of Brevibacterium linens, which is important in the development of the characteristic flavor, color, and aroma of smear surface-ripened cheeses (2).

Extracellular enzymes secreted by $B$. linens include proteinase $(11,12,17)$, aminopeptidase $(5-8,10)$, and esterase (4). The action of these extracellular enzymes at the surface of the cheese results in the production of low-molecular-mass compounds which are capable of diffusing towards the interior of the cheese and are required for the development of the characteristic qualities of these cheeses. The extracellular enzymes themselves are much too large to diffuse into the cheese (15).

Extracellular proteinase activity by $B$. linens has been reported by several authors $(1,4,9,11,12,17,21)$. An extracellular serine proteinase purified from B. linens ATCC 9174 (17) was found to have $\mathrm{pH}$ and temperature optima of 8.5 and $50^{\circ} \mathrm{C}$, respectively, and a molecular mass of $56 \mathrm{kDa}$ by sodium dodecyl sulfate-polyacrylamide gel electrophoresis (SDS-PAGE). The detailed specificity of this extracellular proteinase from $B$. linens ATCC 9174 on bovine $\alpha_{\mathrm{s} 1}$-casein (18) showed that the proteinase had a broad specificity for the amino acid residues present at the $\mathrm{P}_{1}$ and $\mathrm{P}^{\prime}{ }_{1}$ positions but did show a preference for hydrophobic residues at the $\mathrm{P}_{2}, \mathrm{P}_{3}, \mathrm{P}_{4}, \mathrm{P}_{2}^{\prime}, \mathrm{P}_{3}^{\prime}$, and $\mathrm{P}_{4}^{\prime}$ positions. This paper reports the first detailed study of the cleavage sites and the major peptides produced from $\beta$-casein by the extracellular proteinase of B. linens ATCC 9174 .

The extracellular proteinase from B. linens ATCC 9174 was purified to homogeneity by anion-exchange chromatography and hydrophobic interaction chromatography, as described previously (17). To a solution of $50 \mathrm{mg}$ of $\beta$-casein in $5 \mathrm{ml}$ of $50 \mathrm{mM} \mathrm{NH} \mathrm{NCO}_{3}$ buffer $(\mathrm{pH} 8.5 ; 0.05 \%$ [wt/vol] sodium azide), $350 \mu \mathrm{l}$ of a solution of the purified proteinase was added, and the mixture was incubated at $37^{\circ} \mathrm{C}$ for up to $24 \mathrm{~h}$.

\footnotetext{
* Corresponding author. Mailing address: Department of Food Chemistry, University College, Cork, Ireland. Phone: 35321902816. Fax: 35321 270001. E-mail: DYDK6010@IRUCCVAX.UCC.IE.
}

At 5, 10, 20, and 40 min and 1, 2, 4, 6, 9, 11, and $24 \mathrm{~h}$, a sample $(430 \mu \mathrm{l})$ of the reaction mixture was removed, heated at $100^{\circ} \mathrm{C}$ for $10 \mathrm{~min}$ to inactivate the proteinase, and subsequently prepared for SDS-PAGE, urea-PAGE, and high-performance liquid chromatography (HPLC) analysis as described previously (18). Two control samples were included in the experiment, one consisting of $\beta$-casein incubated for $24 \mathrm{~h}$ without added enzyme and the other containing $\beta$-casein and heat-inactivated enzyme.

SDS-PAGE showed that $\beta$-casein was degraded by the extracellular proteinase of $B$. linens (Fig. 1) to lower-molecularweight products over time, with no intact $\beta$-casein remaining after $4 \mathrm{~h}$. A large peptide (between 20 and $24 \mathrm{kDa}$ ) was observed after $5 \mathrm{~min}$ of hydrolysis and reached a maximum by 40 min; however, by $6 \mathrm{~h}$ this intermediate product was completely hydrolyzed. There was a gradual increase of five peptides (between 14.2 and $20 \mathrm{kDa}$ ) from $5 \mathrm{~min}$ to a maximum at $2 \mathrm{~h}$; between 4 and $6 \mathrm{~h}$, these peptides were further hydrolyzed to lower-molecular-mass products, with none of the five peptides remaining after $9 \mathrm{~h}$. Two peptides (less than $6.5 \mathrm{kDa}$ ) were observed after $40 \mathrm{~min}$ of hydrolysis and gradually increased in intensity up to $24 \mathrm{~h}$. Urea-PAGE of the hydrolysis sequence (Fig. 2) showed, in agreement with SDS-PAGE, that no intact $\beta$-casein remained after $4 \mathrm{~h}$. After hydrolysis for $5 \mathrm{~min}$, one major band (at $4.0 \mathrm{~cm}$ ) and one minor band (at $3.5 \mathrm{~cm}$ ) with electrophoretic mobilities between that of $\beta$-casein and $\alpha_{\mathrm{s} 1}$ casein were observed. Both of these bands reached a maximum at $20 \mathrm{~min}$, after which they were degraded to completion by $6 \mathrm{~h}$. These bands were electroblotted from the 5-min hydrolysate of the urea-PAGE gel onto a polyvinylidene difluoride (PVDF) membrane (pore size, $0.22 \mu \mathrm{m}$; ProBlott; Applied Biosystems Inc., Foster City, Calif.) with a Mini Trans-Blott electrophoretic transfer cell (Bio-Rad Laboratories Ltd., Watford, Hertfordshire, United Kingdom). Electroblotting was performed at $90 \mathrm{~V}$ for $15 \mathrm{~min}$ in 3-[cyclohexylamino]1-propanesulfonic acid (CAPS) transfer buffer. The PVDF membranes were then stained with $0.2 \%$ (wt/vol) Coomassie brilliant blue $\mathrm{R}-250$ in $1 \%$ (vol/vol) acetic acid for 10 to $15 \mathrm{~min}$, followed by destaining in $50 \%$ methanol. The N-terminal amino acid sequences of these two bands showed that both contained the $\mathrm{N}$-terminal sequence of $\beta$-casein. Interestingly, between 20 min and $2 \mathrm{~h}$, two peptides with a slower electrophoretic mobility than that of $\beta$-casein were observed; these peptides were 


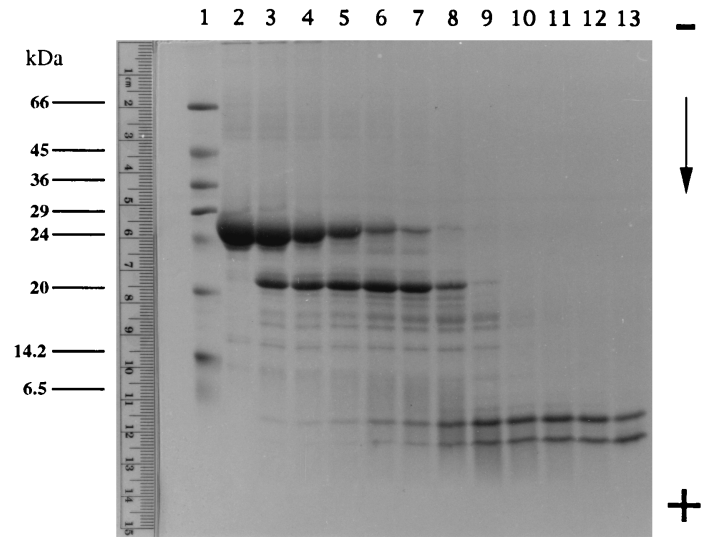

FIG. 1. SDS-PAGE of $\beta$-casein hydrolysates produced by the extracellular proteinase of $B$. linens ATCC 9174. Lane 1, molecular mass markers: bovine serum albumin $(66 \mathrm{kDa})$, ovalbumin $(45 \mathrm{kDa})$, glyceraldehyde-3-phosphate dehydrogenase $(36 \mathrm{kDa})$, carbonic anhydrase $(29 \mathrm{kDa})$, trypsinogen $(24 \mathrm{kDa})$, trypsin inhibitor $(20 \mathrm{kDa}), \alpha$-lactalbumin $(14.2 \mathrm{kDa})$, and aprotinin $(6.5 \mathrm{kDa})$; lane $2, \beta$-casein and heat-inactivated enzyme; lanes 3 to 13 , hydrolysis for 5,10 , 20 , and $40 \mathrm{~min}$ and $1,2,4,6,9,11$, and $24 \mathrm{~h}$, respectively. + , anode; - , cathode.

totally hydrolyzed by $6 \mathrm{~h}$. There was a progressive increase over the 24-h hydrolysis of several minor peptides with high electrophoretic mobilities.

The HPLC profiles of the $\mathrm{pH} 4.6$-soluble peptides in the 40-min, 2-h, 6-h, and 24-h hydrolysates are shown in Fig. 3a to d, respectively. The labelled peaks (Fig. 3e) from the 9-h hydrolysate were isolated and identified by $\mathrm{N}$-terminal amino acid sequencing and mass spectrometry, as described previously (18). The identities of the peptides present in these peaks are listed in Table 1. The peptide bonds of bovine $\beta$-casein found to be susceptible to hydrolysis by the extracellular proteinase from B. linens ATCC 9174 were Ser-18-Ser-19, Glu20-Glu-21, Gln-56-Ser-57, Gln-72-Asn-73, Leu-77-Thr-78, Ala-101-Met-102, Phe-119-Thr-120, Leu-139-Leu-140, Ser142-Trp-143, His-145-Gln-146, Gln-167-Ser-168, Gln-175Lys-176, Tyr-180-Pro-181, and Phe-190-Leu-191. Leucine, glutamine, and phenylalanine were the most frequently occurring amino acid residues at the $\mathrm{P}_{1}$ position; they appeared five, four, and three times, respectively. At the $\mathrm{P}^{\prime}{ }_{1}$ position, serine

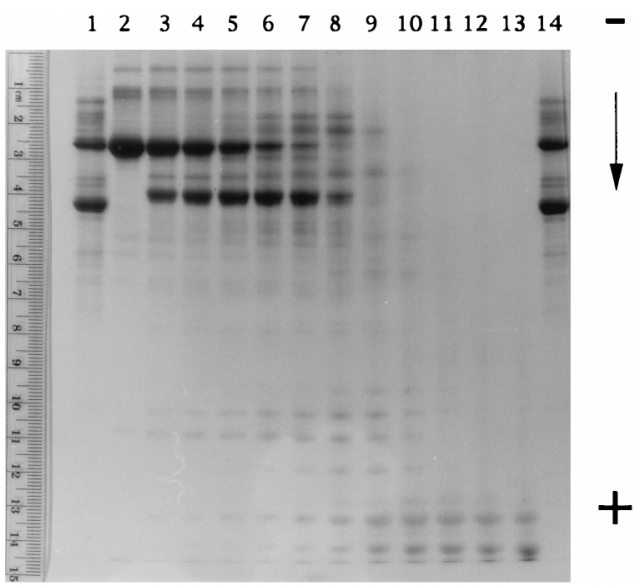

FIG. 2. Urea-PAGE of $\beta$-casein hydrolysates produced by the extracellular proteinase of $B$. linens ATCC 9174. Lanes 1 and 14, sodium caseinate standard; lane 2, $\beta$-casein and heat-inactivated enzyme; lanes 3 to 13 , hydrolysis for 5, 10, 20 , and $40 \mathrm{~min}$ and $1,2,4,6,9,11$, and $24 \mathrm{~h}$, respectively. + , anode; - , cathode.
TABLE 1. Identity of $\mathrm{pH}$ 4.6-soluble peptides produced from $\beta$-casein by the extracellular proteinase of B. linens ATCC 9174

\begin{tabular}{|c|c|c|c|c|}
\hline $\begin{array}{l}\text { Peak } \\
\text { no. }{ }^{a}\end{array}$ & $\mathrm{~N}$-terminal sequence ${ }^{b}$ & $\begin{array}{c}\text { Experi- } \\
\text { mental } \\
\text { mass (Da) }\end{array}$ & $\begin{array}{l}\text { Theoretical } \\
\text { mass (Da) }\end{array}$ & Identity \\
\hline 1 & Lys-Ala-Val-Pro-Tyr & 577.7 & 576.7 & $\beta-\mathrm{CN}(\mathrm{f} 176-180)$ \\
\hline \multirow[t]{3}{*}{2} & Ser-Lys-Val-Leu-Pro & 868.6 & 867.0 & $\beta-\mathrm{CN}(\mathrm{f} 168-175)$ \\
\hline & Pro-Gly-Pro-Ile-His* & $1,061.1$ & $1,059.2$ & $\beta-\mathrm{CN}(\mathrm{f} 63-72)$ \\
\hline & Ser-Gln-Ser-Lys-Val* & $1,084.8$ & $1,082.2$ & $\beta-\mathrm{CN}(\mathrm{f} 166-175)$ \\
\hline \multirow[t]{2}{*}{3} & Leu-Gln-Ser-Trp-Met & 802.4 & 800.9 & $\beta-\mathrm{CN}(\mathrm{f} 140-145)$ \\
\hline & Gly-Val-Ser-Lys-Val* & $\mathrm{ND}^{c}$ & ND & $\beta-\mathrm{CN}(\mathrm{f} 94-98 ?)$ \\
\hline 4 & Pro-Gln-Arg-Asp-Met & $1,204.1$ & $1,202.4$ & $\beta-\mathrm{CN}(\mathrm{f} 181-190)$ \\
\hline \multirow[t]{3}{*}{5} & Lys-Ala-Val-Pro-Tyr & $1,764.1$ & $1,759.9$ & $\beta-\mathrm{CN}(\mathrm{f} 176-190)$ \\
\hline & Val-Tyr-Pro-Phe-Pro* & $1,566.8$ & $1,565.8$ & $\beta-\mathrm{CN}(\mathrm{f} 59-72)$ \\
\hline & Met-Ala-Pro-Lys-His* & ND & ND & $\beta-\mathrm{CN}(\mathrm{f} 102-106 ?)$ \\
\hline \multirow[t]{3}{*}{6} & Ser-Leu-Val-Tyr-Pro & $1,767.3$ & $1,764.9$ & $\beta-\mathrm{CN}(\mathrm{f} 57-72)$ \\
\hline & Thr-Gln-Thr-Pro-Val* & $2,374.7$ & $2,379.3$ & $\beta-\mathrm{CN}(\mathrm{f} 78-99)$ \\
\hline & Met-Ala-Pro-Lys-His* & $2,176.2$ & $2,171.1$ & $\beta-\mathrm{CN}(\mathrm{f} 102-119)$ \\
\hline \multirow[t]{2}{*}{7} & Arg-Glu-Leu-Glu-Glu+ & $2,275.8$ & $2,276.2$ & $\beta-\mathrm{CN}(\mathrm{f} 1-18)$ \\
\hline & Thr-Gln-Thr-Pro-Val* & ND & ND & $\beta-\mathrm{CN}(\mathrm{f} 78-82$ ?) \\
\hline 8 & Arg-Glu-Leu-Glu-Glu & $2,215.0$ & $2,215.1$ & $\beta-\mathrm{CN}(\mathrm{f} 1-20)$ \\
\hline \multirow[t]{3}{*}{9} & Thr-Glu-Ser-Gln-Ser & $2,223.1$ & $2,220.5$ & $\beta-\mathrm{CN}(\mathrm{f} 120-139)$ \\
\hline & Leu-Gln-Ser-Trp-Met* & $3,001.0$ & $2,996.5$ & $\beta-\mathrm{CN}(\mathrm{f} 140-165)$ \\
\hline & Asn-Ile-Pro-Pro-Leu* & ND & ND & $\beta-\mathrm{CN}(\mathrm{f} 73-77 ?)$ \\
\hline 10 & Thr-Glu-Ser-Gln-Ser & $2,541.8$ & $2,548.9$ & $\beta-\mathrm{CN}(\mathrm{f} 120-142)$ \\
\hline 11 & Leu-Leu-Tyr-Gln-Gln & $2,109.4$ & $2,106.6$ & $\beta-\mathrm{CN}(\mathrm{f} 191-209)$ \\
\hline \multirow[t]{2}{*}{12} & Met-Ala-Pro-Lys-His & $4,377.3$ & $4,376.1$ & $\beta-\mathrm{CN}(\mathrm{f} 102-139)$ \\
\hline & Gly-Val-Ser-Lys-Val* & $2,109.4$ & $2,111.5$ & $\beta-\mathrm{CN}(\mathrm{f} 94-112)$ \\
\hline \multirow[t]{2}{*}{13} & Thr-Glu-Ser-Gln-Ser & $3,010.6$ & $3,003.4$ & $\beta-\mathrm{CN}(\mathrm{f} 120-145)$ \\
\hline & Ser-Leu-Ser-Gln-Ser* & $2,226.6$ & $2,223.6$ & $\beta-\mathrm{CN}(\mathrm{f} 164-183)$ \\
\hline
\end{tabular}

${ }^{a}$ See Fig. 3e.

${ }^{b} *$, minor peptides; + , possible phosphorylation at Ser-15, Ser-17, and Ser-18 and peptide association with $\mathrm{K}^{+}$.

${ }^{c} \mathrm{ND}$, not determined.

was observed five times, while glutamate, leucine, lysine, and proline each occurred twice. Therefore, it is apparent that there was no clear specificity for any particular amino acid residue at the $\mathrm{P}_{1}$ and/or $\mathrm{P}^{\prime}{ }_{1}$ positions. Furthermore, both hydrophilic (Gln-72-Asn-73, His-145-Gln-146) and hydrophobic (Leu-139-Leu-140, Phe-190-Leu-191) peptide bonds were cleaved by the proteinase. However, examination of the $\mathrm{P}_{2}, \mathrm{P}_{3}$, $\mathrm{P}_{4}, \mathrm{P}_{2}^{\prime}, \mathrm{P}_{3}^{\prime}$, and $\mathrm{P}_{4}^{\prime}$ positions around the susceptible bond showed that the amino acid residues found at these positions, while not exclusively hydrophobic, were generally so. $\beta$-Casein is an amphipathic molecule containing a highly charged $\mathrm{N}$ terminal region, residues 1 to 21 , while the $\mathrm{C}$-terminal region is very hydrophobic (20). The vast majority of bonds hydrolyzed by the proteinase were confined to the hydrophobic region of the molecule, with only one cleavage site in the highly charged region, i.e., Ser-18-Ser-19. This may suggest that hydrophobicity is important for enzyme-substrate binding, while cleavage of the peptide bond is not critically dependent on the actual amino acid present at the $\mathrm{P}_{1}$ and $\mathrm{P}^{\prime}{ }_{1}$ positions. This type of broad enzyme specificity was also found for the action of the extracellular proteinase of $B$. linens ATCC 9174 on $\alpha_{\mathrm{s} 1}$-casein (18) and for the cell wall-associated proteinase from Lactococcus lactis subsp. cremoris and Lactococcus lactis subsp. lactis on $\alpha_{\mathrm{s} 1}$-casein and $\beta$-casein $(19,22,23)$.

A recognized problem associated with cheese ripening is the development of bitterness due to the hydrolysis of the $\mathrm{C}$ terminal region of $\beta$-casein, with the production of bittertasting peptides, such as $\beta-\mathrm{CN}$ (f196-209), $\beta-\mathrm{CN}$ (f202-209), and $\beta$-CN(f203-209) (20). Hydrolysis of $\beta$-casein by the extracellular proteinase of $B$. linens ATCC 9174 produced none of these typically bitter peptides (Table 1 ), indicating that any bitter- 

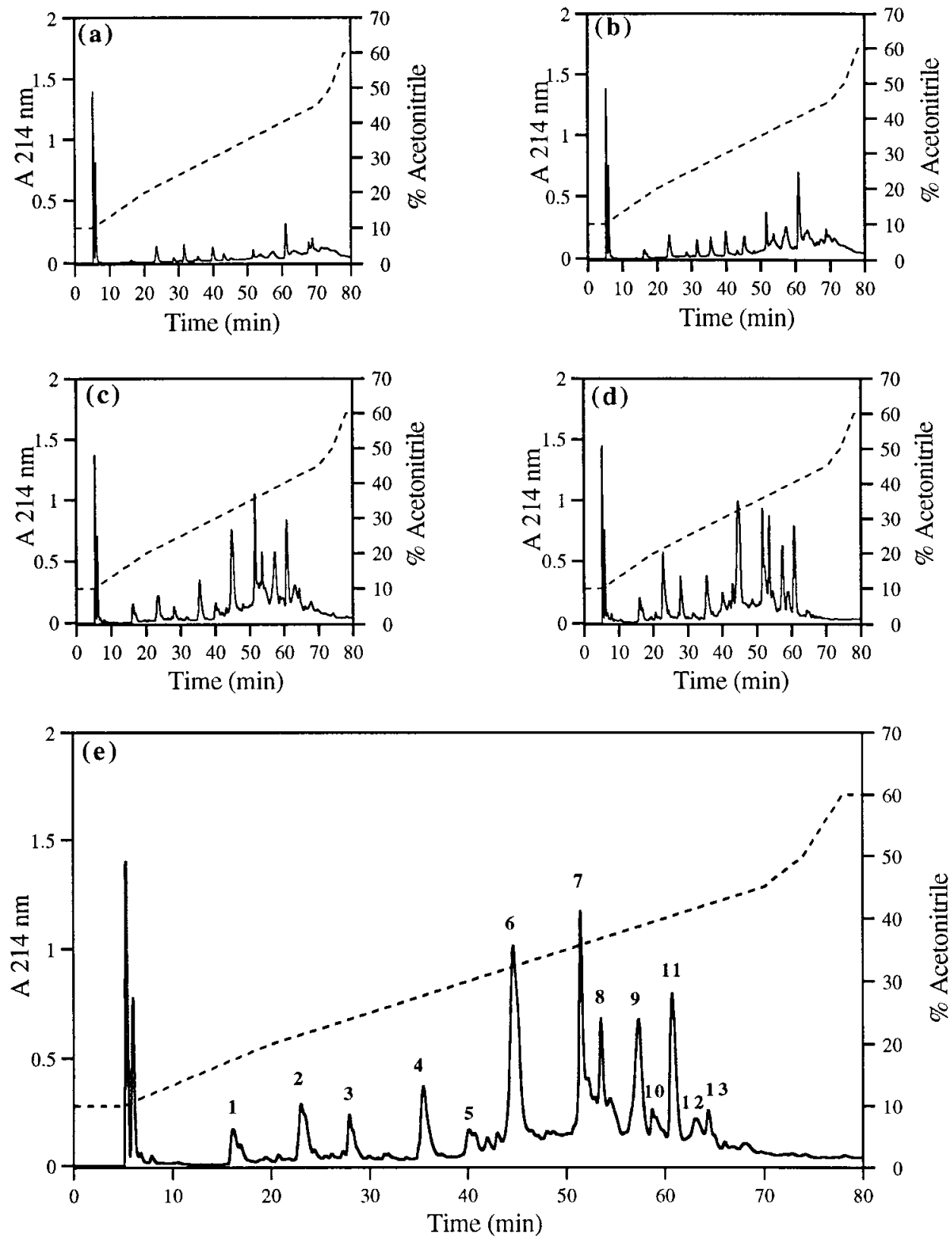

FIG. 3. HPLC profiles of $\mathrm{pH}$ 4.6-soluble peptides in the hydrolysates of $\beta$-casein produced by the extracellular proteinase of $B$. linens ATCC 9174. (a to d) Hydrolysis for $40 \mathrm{~min}$ and 2, 6, and $24 \mathrm{~h}$, respectively. (e) Hydrolysis for $9 \mathrm{~h}$. Labelled peaks, 1 to 13, were isolated and identified by $\mathrm{N}$-terminal sequencing and mass spectrometry.

ness associated with smear surface-ripened cheeses would not be directly attributable to the extracellular proteinase of $B$. linens. However, the extracellular proteinase did produce the fragment $\beta-\mathrm{CN}(\mathrm{f} 191-209)$, which could act as a potential substrate for the production of bitter peptides as a result of hydrolysis by the extracellular aminopeptidase of B. linens (5-8, 10). Bioactive peptides with opioid-type activity, such as $\beta-\mathrm{CN}(\mathrm{f} 60-63), \beta-\mathrm{CN}(\mathrm{f} 60-64), \beta-\mathrm{CN}(\mathrm{f} 60-65)$, and $\beta-\mathrm{CN}(\mathrm{f} 60-$ $66)$, may be produced as a result of the hydrolysis of $\beta$-casein (20); no such bioactive peptides were produced from $\beta$-casein by the extracellular proteinase of $B$. linens ATCC 9174.

Future research in this area would involve the isolation of peptides from typical smear surface-ripened cheeses such as
Limburger, Trappist, Brick, Tilsiter, and Münster. The production of such cheese-derived peptides is a result of the action of the coagulant, starter, and surface microflora. The direct comparison of these cheese-derived peptides with the peptides identified here would enable evaluation of the significance of the extracellular proteinase from $B$. linens in the ripening process of bacterial smear surface-ripened cheeses.

We thank Kevin Bailey, Department of Biochemistry, University of Nottingham, Nottingham, United Kingdom, for mass spectrometry analysis. The technical assistance of Eugene O'Connor, Department of Food Chemistry, University College, Cork, Ireland, is also appreciated. 
The project was funded in part from European Union structural funds from its Food Sub-Programme of the Industry Programme.

\section{REFERENCES}

1. Ades, G. L., and J. F. Cone. 1969. Proteolytic activity of Brevibacterium linens during ripening of Trappist-type cheese. J. Dairy Sci. 52:957-961.

2. Boyaval, P., and M. J. Desmazeaud. 1983. Le point des connaissances sur Brevibacterium linens. Lait 63:187-216.

3. El-Erian, A. 1969. Bacteriological studies on Limburger cheese. Thesis. Agricultural University, Wageningen, The Netherlands.

4. Foissy, H. 1974. Examination of Brevibacterium linens by an electrophoretic zymogram technique. J. Gen. Microbiol. 80:197-207.

5. Foissy, H. 1978. Aminopeptidase from Brevibacterium linens: production and purification. Milchwissenschaft 33:221-223.

6. Foissy, H. 1978. Aminopeptidase from Brevibacterium linens: activation and inhibition. Lebensm. Unters. Forsch. 166:164-166.

7. Foissy, H. 1978. Kinetic properties of Brevibacterium linens aminopeptidase, p. 479-480 (E). In Proceedings of the 20th International Dairy Congress (Paris).

8. Foissy, H. 1978. Some properties of aminopeptidase from Brevibacterium linens. FEMS Microbiol. Lett. 3:207-210.

9. Friedman, M., W. Nelson, and W. Wood. 1953. Proteolytic enzymes from Bacterium linens. J. Dairy Sci. 36:1124-1134.

10. Hayashi, K., and B. A. Law. 1989. Purification and characterization of two aminopeptidases produced by Brevibacterium linens. J. Gen. Microbiol. 135: 2027-2034.

11. Hayashi, K., A. J. Cliffe, and B. A. Law. 1990. Purification and preliminary characterization of five serine proteinases produced by Brevibacterium linens. Int. J. Food Sci. Technol. 25:180-187.

12. Juhász, O., and B. Skárka. 1990. Purification and characterization of an extracellular proteinase from Brevibacterium linens. Can. J. Microbiol. 36:
$510-512$.

13. Kelly, C. D. 1937. The microbiological flora on the surface of Limburger cheese. J. Dairy Sci. 20:239-246.

14. Langhus, W. L., W. V. Price, H. H. Sommer, and W. C. Frazier. 1945. The "smear" of Brick cheese and its relation to flavour development. J. Dairy Sci. 28:827-838.

15. Meyer, J., M. Casey, and J. Gruskovnjak. 1985. Diffusion des peptidases dans le Gruyère. Schweiz. Milchwirtsch. Forsch. 14:11-15.

16. Purko, M., W. O. Nelson, and W. A. Wood. 1951. The associative action between certain yeasts and Bacterium linens. J. Dairy Sci. 34:699-705.

17. Rattray, F. P., W. Bockelmann, and P. F. Fox. 1995. Purification and characterization of an extracellular proteinase from Brevibacterium linens ATCC 9174. Appl. Environ. Microbiol. 61:3454-3456.

18. Rattray, F. P., P. F. Fox, and A. Healy. 1996. Specificity of an extracellular proteinase from Brevibacterium linens ATCC 9174 on bovine $\alpha_{\mathrm{s} 1}$-casein. Appl. Environ. Microbiol. 62:501-506.

19. Reid, J. R., C. H. Moore, G. G. Midwinter, and G. G. Pritchard. 1991. Action of a cell wall proteinase from Lactococcus lactis subsp. cremoris SK11 on bovine $\alpha_{\mathrm{s} 1}$-casein. Appl. Microbiol. Biotechnol. 35:222-227.

20. Swaisgood, H. E. 1992. Chemistry of the caseins, p. 63-110. In P. F. Fox (ed.), Advanced dairy chemistry, vol. 1. Proteins. Elsevier Applied Science, New York, N.Y.

21. Tokita, F., and A. Hosono. 1972. Studies on the extracellular protease produced by Brevibacterium linens. Production and some properties of the extracellular protease. Jpn. J. Zootech. Sci. 43:39-48.

22. Visser, S., A. J. Robben, and C. J. Slagen. 1991. Specificity of a cell-envelopelocated proteinase ( $\mathrm{P}_{\mathrm{III}}$-type) from Lactococcus lactis subsp. cremoris AM1 in its action on bovine $\beta$-casein. Appl. Microbiol. Biotechnol. 35:477-484.

23. Visser, S., C. J. Slagen, F. A. Exterkate, and G. J. de Veer. 1988. Action of a cell wall proteinase $\left(\mathrm{P}_{\mathrm{I}}\right)$ from Streptococcus cremoris HP on bovine $\beta$-casein. Appl. Microbiol. Biotechnol. 29:61-66. 